\title{
KEPADATAN DAN POLA PERTUMBUHAN TERIPANG Holothuria scabra, Holothuria atra dan Bohadchia marmorata SERTA ASOSIASINYA DENGAN LAMUN DI PESISIR PULAU AMBON, SAPARUA, OSI DAN MARSEGU, PROVINSI MALUKU
}

\section{DENSITY AND GROWTH PATTERN OF SEA CUCUMBERS Holothuria scabra, Holothuria atra and Bohadchia marmorata AND THEIR ASSOCIATION WITH SEAGRASS IN COASTAL AREA OF AMBON, SAPARUA, OSI AND MARSEGU ISLAND, MALUKU PROVINCE}

\author{
Yunita Luhulima $^{{ }^{*}}$, Neviaty P. Zamani ${ }^{2}, \&$ Dietriech G. Bengen ${ }^{2}$ \\ ${ }^{1}$ Program Studi Ilmu Kelautan, Sekolah Pascasarjana, IPB University, Bogor, 16680, Indonesia \\ ${ }^{2}$ Departemen Ilmu dan Teknologi Kelautan, FPIK, IPB University, Bogor, 16680, Indonesia \\ *E-mail: yunitaluhulima@yahoo.co.id
}

\begin{abstract}
Holothuria scabra, Holothuria atra, and Bohadschia marmorata are sea cucumber species with very diverse habitat and commonly dominant than other species. This study aims to analyze the density and growth pattern sea cucumbers of Holothuria scabra, Holothuria atra, and Bohadschia marmorata and their association with seagrass Ambon, Osi, and Marsegu Island. The association of sea cucumber and seagrass was analyzed using Correspondence Analysis (CA). The research was conducted in October 2019 to November 2019. Sampling was carried out at three stations representing each location by using a $\mathrm{Im}^{2}$ quadrant. The results show that sea cucumber density ranged from 4.0 to 6.6 ind/100 $\mathrm{m}^{2}$. Overall, sea cucumber's growth pattern is a negative allometric of which the length growth is faster than the weight growth. Thalassia hemprichii is one of the seagrass species with the highest density (64407 ind/100 $\left.\mathrm{m}^{2}\right)$, while Halodule pinifolia has the lowest density $\left(900 \mathrm{ind} / 100 \mathrm{~m}^{2}\right)$. The result of the correspondence analysis showed that there is three association group between sea cucumber and seagrass. The overall result shows that seagrass density affects the density and distribution of sea cucumber.
\end{abstract}

Keywords: density, deposit feeder, Holothuroidea

\begin{abstract}
ABSTRAK
Holothuria scabra, Holothuria atra dan Bohadschia marmorata merupakan jenis teripang dengan habitat yang sangat beragam dan umumnya ditemukan dalam jumlah yang dominan dibandingkan jenis lainnya. Penelitian ini bertujuan untuk menganalisis kepadatan dan pola pertumbuhan teripang $H$. scabra, H. atra dan B. marmorata serta asosiasinya dengan jenis lamun di pesisir Pulau Ambon, Pulau Osi dan Pulau Marsegu. Asosiasi teripang dengan lamun dianalisis dengan menggunakan analisis koresponden (CA). Penelitian dilakukan pada bulan Oktober 2019 sampai November 2019. Pengambilan sampel dilakukan pada pada 3 stasiun yang mewakili masing-masing lokasi dengan menggunakan kuadran $1 \mathrm{~m}^{2}$. Hasil penelitian mendapatkan kepadatan teripang berkisar dari 4,0 sampai $6,6 \mathrm{ind} / 100 \mathrm{~m}^{2}$. Secara keseluruhan pola pertumbuhan teripang adalah allometrik negatif dimana pertumbuhan panjang lebih cepat dibandingkan dengan pertumbuhan berat. Thalassia hemprichii merupakan jenis lamun dengan kerapatan tertinggi sebesar $64407 \mathrm{ind} / 100 \mathrm{~m}^{2}$ dan Halodule pinifolia adalah jenis terendah sebesar $900 \mathrm{ind} / 100 \mathrm{~m}^{2}$. Hasil koresponden analisis menunjukkan adanya tiga kelompok asosiasi antara teripang dengan lamun. Berdasarkan hasil penelitian menunjukkan bahwa Perbedaan jenis lamun dan kerapatan lamun berdampak pada kepadatan dan penyebaran jenis teripang.
\end{abstract}

Kata kunci: deposit feeder, Holothuridae, kerapatan 


\section{PENDAHULUAN}

Teripang merupakan komponen utama padang lamun (Hamel et al., 2001) yang tergolong dalam filum Echinodermata, kelas Holothuridae dengan nama lain beche-demer atau gamet. Umumnya teripang terdistribusi di seluruh samudra dan hidup pada daerah perairan dangkal yang dekat dengan lamun, rumput laut, dan terumbu karang sampai pada kedalaman $20 \mathrm{~m}$ dengan kondisi perairan yang tidak tercemar. Teripang dikenal memiliki peran ekologis sebagai deposit feeder sehingga mampu mengolah substrat yang ditempatinya sebagai penyedia makanan dalam bentuk telur, larva dan juvenil bagi biota laut (Purcell et al., 2016). Pada tahun 2008 Kementerian Kelautan Perikanan (KKP) melaporkan bahwa volume produksi teripang di Maluku meningkat menjadi 563 ton dengan penjualan senilai Rp58.300.500.000,00 peningkatan ini dipengarui oleh tingginya permintaan pasar global untuk memenuhi kebutuhan konsumsi dan farmasi, hal ini dikarenakan teripang merupakan sumber bahan makanan di beberapa negara bagian Asia dan Timur Tengah serta berperan sebagai sumber obat-obatan untuk mengatasi berbagai jenis penyakit (Bordbar, 2011). Akibatnya, sangat berdampak pada populasi teripang di alam.

Ekosistem lamun menjadi habitat yang sangat baik untuk kehidupan teripang karena memiliki produktifitas primer yang tinggi dan mendapat pasokan nutrien secara langsung dari daratan sehingga ekosistem ini sangat kaya akan kandungan bahan organik (Bengen, 2001). Lamun dapat ditemukan pada zona intertidal jernih dengan sirkulasi air yang baik, substrat lumpur berpasir dan kaya akan bahan organik sampai pada kedalaman $40 \mathrm{~m}$ (Newmaster et al., 2011; Short \& Novak, 2016).

Beragamnya jenis lamun dan jenis substrat akan memengaruhi kelimpahan, dan jenis teripang di alam, Guliano et al. (2014) menyatakan bahwa kepadatan teripang terendah ditemukan pada ekosistem lamun, hal ini berbeda dengan hasil penelitian Ristina et al. (2018) bahwa kepadatan teripang ditemukan paling rendah pada kerapatan lamun yang jarang dan sebaliknya teripang paling tinggi ditemukan pada kerapatan lamun yang padat dengan hubungan korelasi $r$ sebesar 0,914. Beberapa jenis teripang yang terkenal, dan memiliki distribusi yang luas adalah $H$. scabra, $H$. atra dan $B$. marmorata, menjadi sangat menarik untuk dikaji sehingga tujuan dari penelitian ini adalah menganalisis kepadatan dan pola pertumbuhan $H$. scabra, $H$. atra dan $B$. marmorata serta asosiasinya dengan lamun di pesisir Pulau Ambon, Pulau Saparua, Pulau Osi, dan Pulau Marsegu.

\section{METODE PENELITIAN}

\subsection{Waktu dan Lokasi Penelitian}

Penelitian ini dilakukan dari Bulan Oktober sampai dengan November 2017 di Pulau Ambon (Suli), Pulau Saparua (Paperu), Pulau Osi, dan Pulau Marsegu, Provinsi Maluku (Figure 1).

\subsection{Penentuan Stasiun}

Setiap lokasi penelitian ditetapkan 3 stasiun penelitian yang mewakili masingmasing lokasi. Setiap stasiun dibagi menjadi 3 substasiun. Substasiun ditempatkan tegak lurus (line transek) dari pesisir pantai menuju laut sampai pada batas daerah lamun. Jarak antara sub-sub stasiun adalah $50 \mathrm{~m}$ dan jarak antar kuadran adalah $20 \mathrm{~m}$. Total kuadran pada Pulau Ambon adalah 129, yang terdiri dari lokasi Suli 82 kuadran dan lokasi Peperu 47 kuadran, Pulau Osi 68 kuadran, dan Pulau Marsegu 51 kuadran.

\subsection{Pengambilan Data Lamun dan Data Teripang}

Pada setiap transek garis dibentangkan kuadran 1 x $1\left(1 \mathrm{~m}^{2}\right)$ untuk pengambilan sampel lamun dan pada transek yang sama juga dilakukan pengambilan data teripang. Sampel lamun yang dilihat adalah komposisi jenis (English et al., 1994), dan kerapatan 


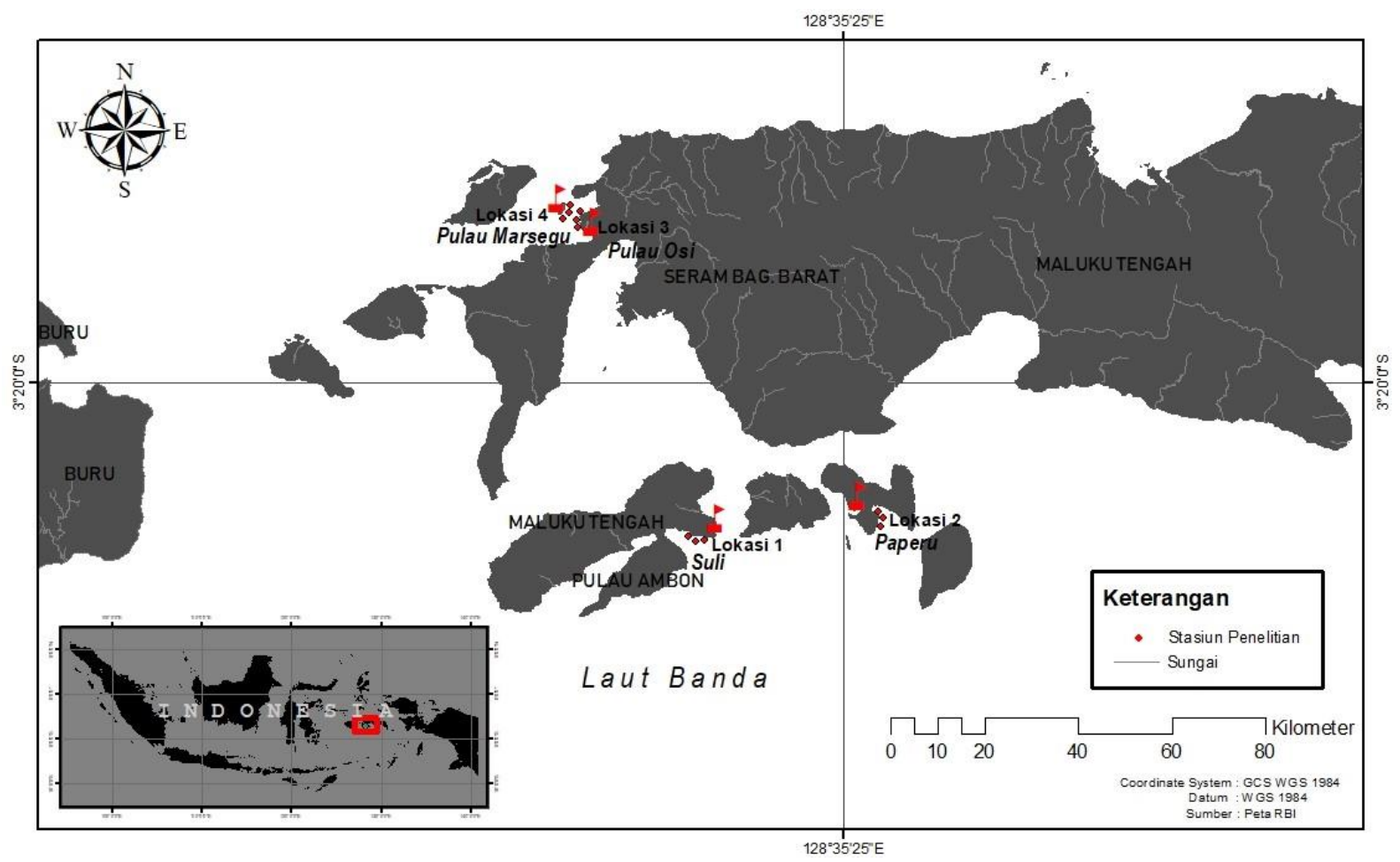

Figure 1. Map of sampling site in Ambon, Saparua, Osi, and Marsegu Islands, Maluku Province.

jenis, sedangkan transek teripang diidentifikasi untuk jenis $H$. scabra, $H$. atra, dan $B$. marmorata berdasarkan (Purcell et al., 2014), menghitung kepadatan teripang dan melakukan pengukuran berupa panjang dan berat, setelah pengukuran tersebut dilakukan sampel teripang dikembalikan ke habitatnya.

\subsection{Analisis Data}

\subsubsection{Kepadatan Teripang}

Kepadatan teripang dihitung dengan menggunakan rumus menurut Krebs (1978):

$N=\frac{\sum n_{i}}{A}$

Keterangan: $N$ adalah kepadatan teripang $\left(\mathrm{ind} / \mathrm{m}^{2}\right) ; \sum n_{i}$ adalah jumlah total jenis-i (individu); $A$ adalah luas area $\left(\mathrm{m}^{2}\right)$.

\subsubsection{Hubungan Panjang Berat dan Faktor Kondisi}

Pengukuran hubungan panjang berat teripang dianalisis berdasarkan Ricker (1975) sedangkan faktor kondisi dianalisis berdasarkan Le Cren (1951):

$W=a L^{b}$ dan $K_{n}=W / W^{*}$.

Keterangan: $W$ adalah berat basah teripang (gram); $a$ adalah intersep (perpotongan kurva hubungan panjang berat dengan sumbu $-\mathrm{y}$ ); $L$ adalah panjang teripang $(\mathrm{cm}) ; b$ adalah koefisien hubungan panjang berat; $K_{n}$ adalah faktor kondisi relatif; $W^{*}$ adalah berat teripang yang teramati berdasarkan persamaan hubungan Panjang berat; $L$ adalah panjang teripang $(\mathrm{cm})$.

\subsubsection{Kerapatan Jenis Lamun}

Kerapatan jenis $(\mathrm{Ki})$ dianalisis berdasarkan English et al. (1994):

$K_{i}=\frac{\Sigma n_{i}}{A}$

Keterangan: $K_{i}$ adalah kerapatan jenis i; $\Sigma n_{i}$ 
adalah jumlah total individu ke i; $A$ adalah luas total area pengambilan contoh $\left(\mathrm{m}^{2}\right)$.

Kerapatan jenis lamun selanjutnya dibagi menjadi lima kelas kerapatan sebagaimana pada Table 1 (Braun-Blanquet, 1965).

Table 1. Type of density class of seagrass.

\begin{tabular}{ccl}
\hline Level & $\begin{array}{c}\text { Density } \\
\left(\mathrm{ind} / 100 \mathrm{~m}^{2}\right)\end{array}$ & \multicolumn{1}{c}{ Category } \\
\hline 1 & $<2,500$ & Rarely \\
2 & $>2,500-7,500$ & Rare \\
3 & $>7,500-12,500$ & Rather tight \\
4 & $>12,500-17,500$ & Tight \\
5 & $>17,500$ & Tightly \\
\hline
\end{tabular}

\subsubsection{Asosiasi Teripang dan Lamun}

Asosiasi antara jenis teripang dan jenis lamun menggunakan matriks data yang terdiri dari jenis teripang pada baris dan jenis lamun pada kolom. Data selanjutnya dianalisis dengan menggunakan Analisis Koresponden (Correspondence Analysis, CA) (Bengen, 2000). Analisis ini didasarkan pada matriks data i (kerapatan lamun dan kepadatan teripang) dan $\mathrm{j}$ kolom (stasiun), kepadatan teripang dan kerapatan lamun yang ditemukan ataupun vegetasi untuk stasiun ke-j pada baris ke-i dan kolom ke-j.

\section{HASIL DAN PEMBAHASAN}

\subsection{Kepadatan Teripang}

Kapadatan setiap jenis teripang sangat bervariasi setiap stasiun (Dissanayake $\&$ Stefasson, 2012). Kepadatan teripang yang ditemukan pada lokasi penelitian (Figure 2 dan Figure 3) berkisar dari 3,2 sampai 7,4 ind $/ 100 \mathrm{~m}^{2}$. Kepadatan tertinggi ditemukan pada jenis $H$. scabra. Kepadatan total masing-masing jenis $H$. scabra, $H$. atra dan B. marmorata di lokasi Suli adalah 19,8 ind/100 $\mathrm{m}^{2}, \quad 12,6$ ind $/ 100 \mathrm{~m}^{2}$ dan 15,3 ind $/ 100 \mathrm{~m}^{2}$, Paperu adalah $14,1 \mathrm{ind} / 100 \mathrm{~m}^{2}$, $14,8 \mathrm{ind} / 100 \mathrm{~m}^{2}$, dan $12 \mathrm{ind} / 100 \mathrm{~m}^{2}$. Osi 17,2 ind/100 m², 14,4 ind/100 m², 14,1 ind/100 m² dan Marsegu hanya ditemukan $H$. scabra $15,3 \mathrm{ind} / 100 \mathrm{~m}^{2}$, dan $H$. atra $14,6 \mathrm{ind} / 100 \mathrm{~m}^{2}$ dengan total kepadatan ketiga jenis pada Suli 47,74 Paperu 40,9 Osi 45,7 dan Marsegu $29,9 \mathrm{ind} / 100 \mathrm{~m}^{2}$.

Tinggi rendahnya kepadatan teripang pada suatu perairan umumnya dipengaruhi oleh faktor alam yaitu daya dukung lingkungan dan cara hidup yang soliter (Lee et al., 2008; Namukose et al., 2016; Mulyani et al., 2017) juga menambahkan bahwa kehadiran predator dapat menjadi indikator menurunnya kepadatan teripang di alam karena terjadi persaingan untuk memperoleh ruangan dan

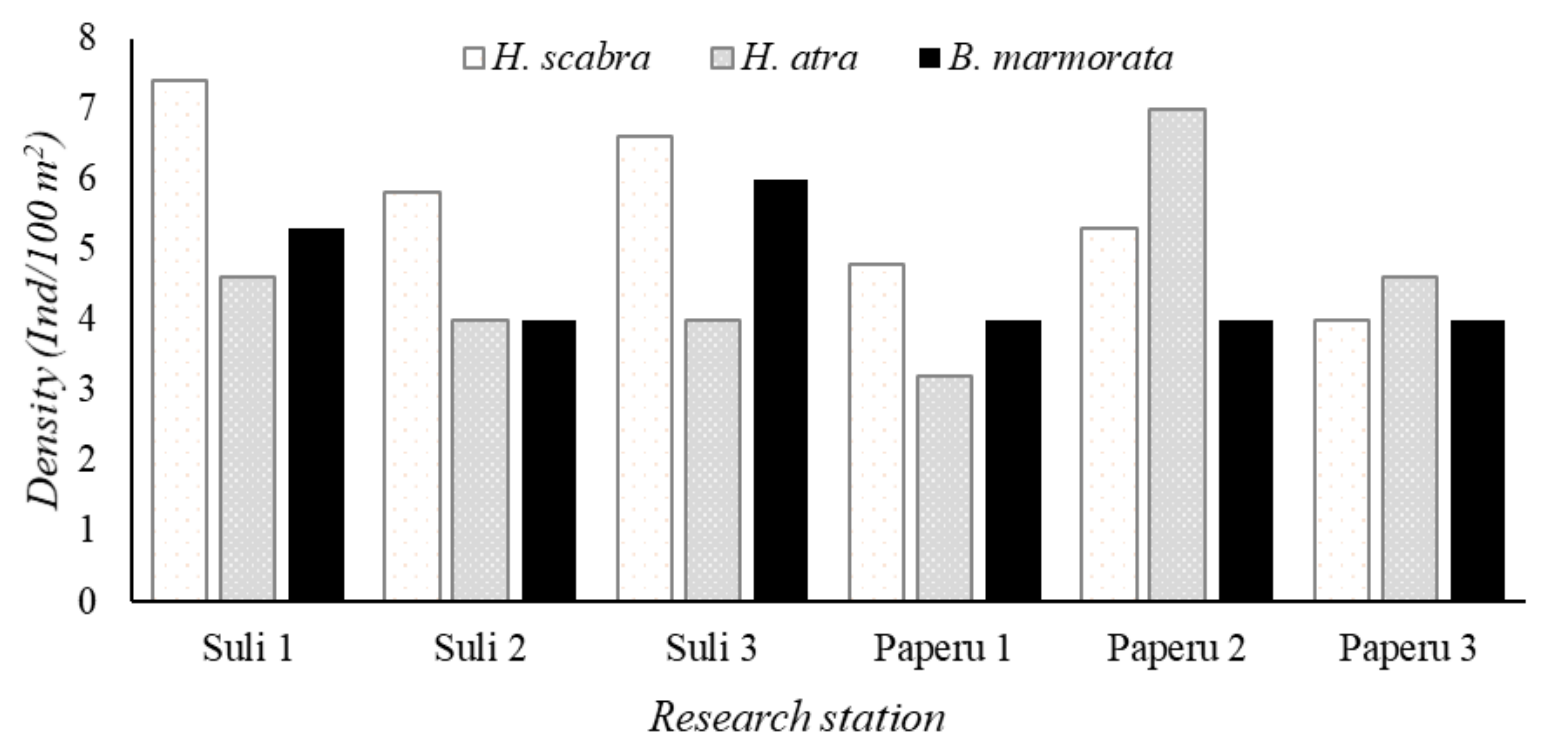

Figure 2. Density of H. scabra, H. atra and B. marmorata in Ambon Island (Suli dan Paperu). 


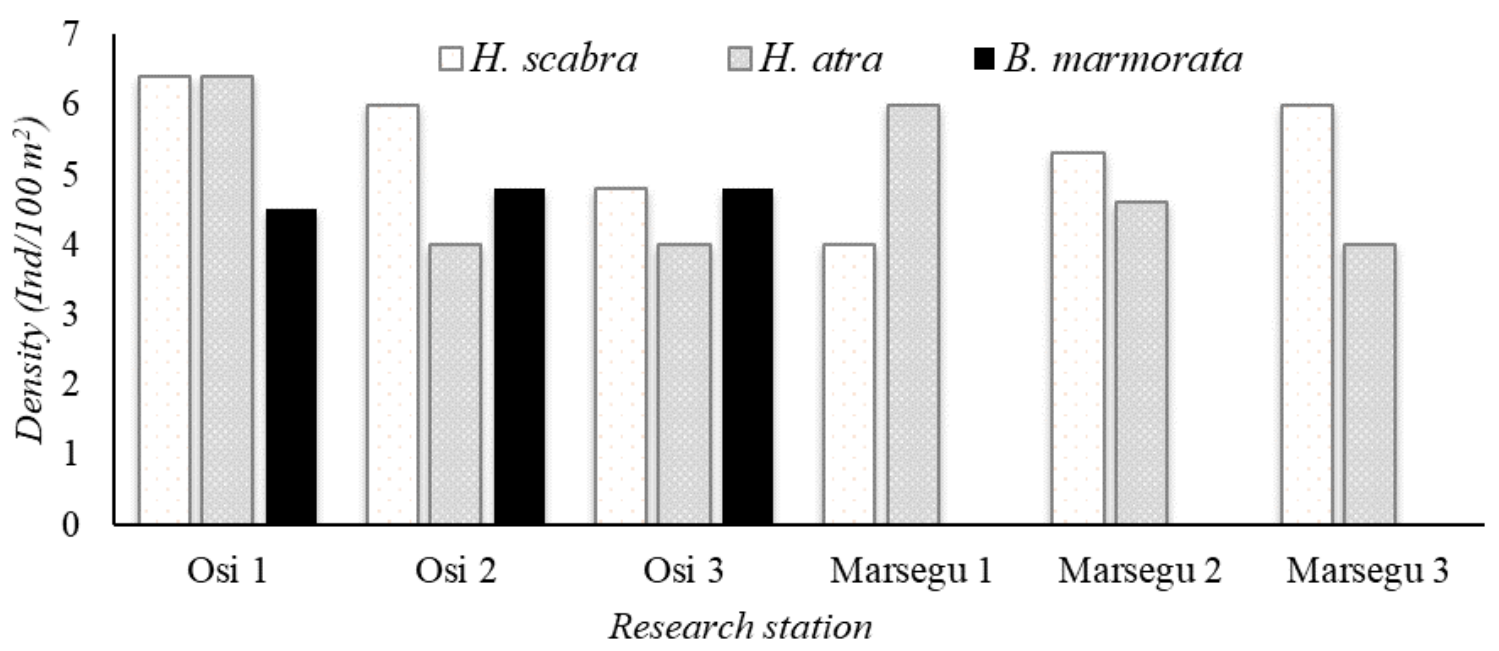

Figure 3. Density of H. scabra, H. atra, B. marmorata in Osi and Marsegu Islands.

habitat. Gutierrez et al. (2014) menyatakan bahwa predator dari teripang adalah kepiting, bintang laut, isopoda dan bulu babi berukuran besar. Tingginya kepadatan teripang di lokasi Suli diduga karena tersedianya sumber bahan makanan berupa nutrien yang sangat tinggi yang berasal dari ekosistem mangrove, sedangkan rendahnya kepadatan teripang di Pulau Marsegu diduga dipengaruhi oleh tingginya predator berupa bulu babi Diadema setasum pada Pulau Marsegu stasiun 1, stasiun 2, dan stasiun 3, sehingga kepadatan teripang lebih besar ditemukan pada Pulau Ambon lokasi Suli dan Pulau Osi. Selain itu tingginya tingkat tekanan ekologis dari masyarakat juga turut memengaruhi kepadatan teripang di alam, pada lokasi Pulau Marsegu diduga memiliki tingkat eksploitasi sangat tinggi sehingga kepadatan teripang pada lokasi ini sangat rendah.

Jenis $H$. scabra memiliki kepadatan yang tertinggi dibandingkan $H$. atra dan $B$.

marmorata. Hal ini diduga karena jenis teripang ini memiliki kemampuan untuk bertahan hidup pada berbagai habitat, sehingga memiliki banyak kesempatan untuk berkembang. Hasan (2005) menyatakan bahwa daerah dengan substrat berpasir merupakan habitat yang paling cocok untuk $H$. scabra, dan keseluruhan lokasi penelitian didominasi oleh pasir.

Penelitian ini sejalan dengan hasil penelitian Dissanayake \& Stefansson (2010) yang menemukan bahwa teripang jenis holothuria memiliki frekuensi kehadiran tertinggi dibandingakan dengan jenis teripang lainnya, serta penelitian Yusron \& Widianwari (2004) yang menemukan bahwa teripang jenis holothuria dengan frekuensi kehadiran tertinggi yaitu $H$. scabra sebesar $60 \%$, H. atra $36,24 \%$ dan B. marmorata sebesar $16,14 \%$.

\subsection{Hubungan Panjang dan Berat}

Hasil analisis hubungan panjang berat menunjukkan bahwa teripang $H$. atra, $H$. scabra, dan B. marmorata memiliki pola pertumbuhan yang sama yaitu allometrik negative. Pertumbuhan panjang lebih cepat dibandingkan dengan pertambahan berat yang dapat terlihat dari nilai $\mathrm{b}<3$ (Figure 4). Hasil ini sesuai dengan penelitian Kaenda et al. (2016) serta Fagetti \& Villalobos (2016). Nilai koefisien determinasi dari persamaan panjang berat menujukkan bahwa $56 \%$ sampai $67 \%$ data pertumbuhan berat dapat terlihat dari model pertumbuhan panjang dan berat. Faktor lain juga turut memengaruhi pertumbuhan teripang seperti faktor internal yaitu umur, dan jenis kelamin serta faktor eksternal berupa suhu, $\mathrm{pH}$, kandungan oksigen terlarut, makanan, dan kompetitor atau predator (Hartati et al., 2017). Keterkaitan antara variabel panjang berat 

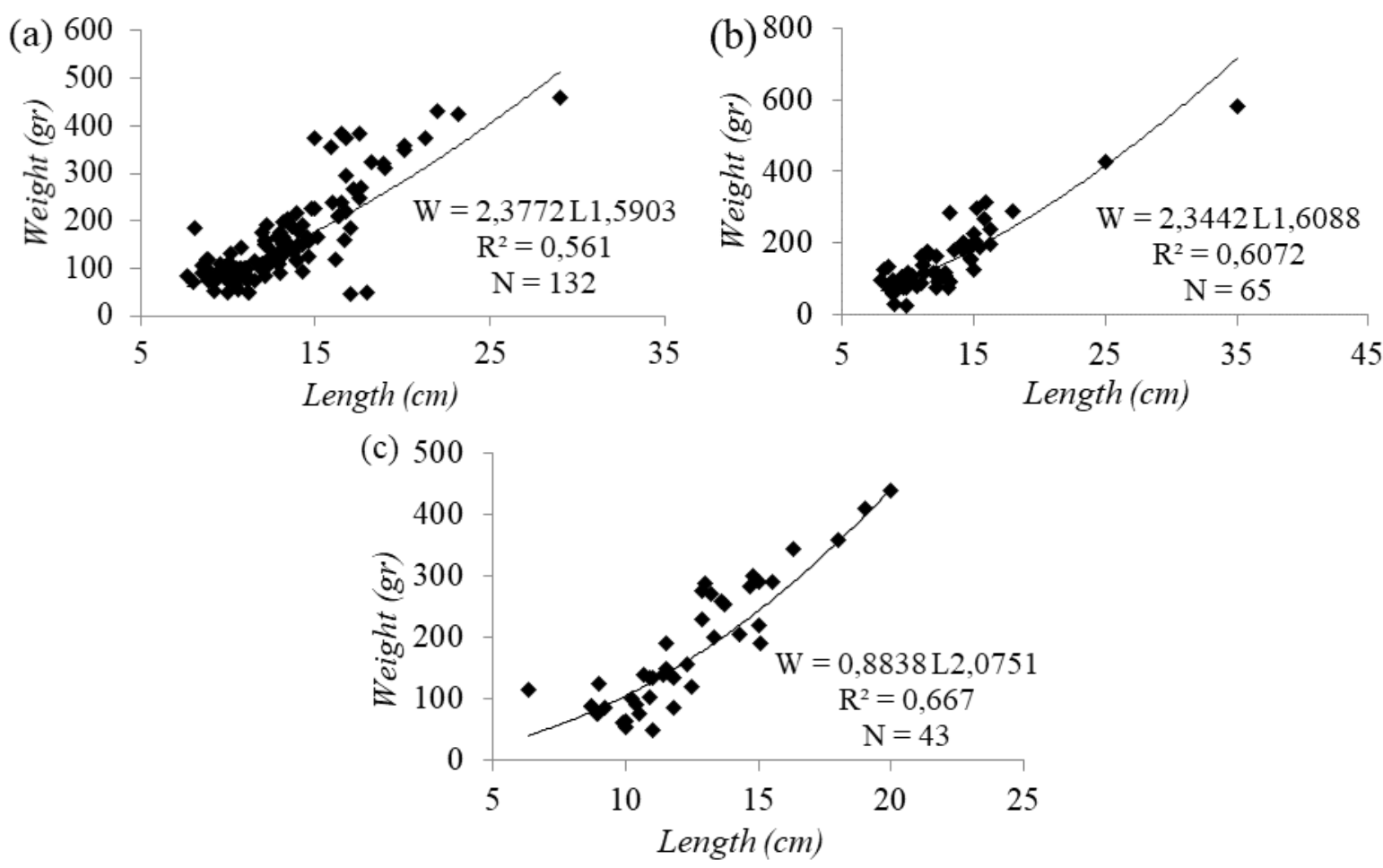

Figure 4. Length-Weight relationship of $H$. atra (a), H. scabra (b), and B. marmorata (c).

dengan nilai koefisien korelasinya (r) mencapai 0,74 sampai 0,81 yang menunjukkan bahwa pertumbuhan panjang berpengaruh terhadap pertambahan berat, hal ini diduga karena teripang banyak mengandung air sehingga bentuk tubuhnya semakin panjang tetapi jika airnya dikeluarkan dari tubuhnya maka tubuh teripang akan semakin kecil atau mengerut. Hubungan pertumbuhan panjang dan berat teripang ini juga dipengaruhi oleh karakteristik lingkungan perairan. Tingginya tekanan lingkungan akan sangat mengganggu keseimbangan tubuh. Hal ini mengakibatkan sebagian besar energi digunakan teripang untuk penyesuaian diri terhadap kondisi yang kurang mendukung dan merusak sistem pencernaan serta transportasi zat-zat makanan dalam darah (Kaenda at al., 2016). Teripang cenderung memodifikasi perilaku makan dan kemampuan pencernaannya mampu mengoptimalkan asupan nutrisi dari perairan dan substrat (Zamora \& Jeffs, 2011)

Hasil perhitungan faktor kondisi $\left(K_{n}\right)$ ketiga jenis teripang menunjukkan nilai $>1$ dimana $H$. atra dan B. marmorata sebesar 1,11 sedangkan $H$. Scabra sebesar 1,10. Hasil ini mengindikasikan bahwa kondisi teripang pada keempat lokasi penelitian masih tergolong baik terutama beratnya. Kandungan makanan yang tersedia pada lokasi penelitian masih tergolong baik untuk mendukung kelangsungan hidup teripang dengan kepadatan yang berbeda-beda. Hal ini sejalan dengan Effendie (1979) yang menjelaskan bahwa faktor kondisi dapat menunjukkan keadaan, baik suatu biota yang terlihat secara fisik dan biologi untuk bertahan hidup dan bereproduksi, serta sangat berguna untuk menganalisis populasi yang disebabkan oleh pengaruh makanan, jenis kelamin dan kematangan gonad.

\subsection{Kerapatan Jenis Lamun}

Total jenis lamun yang ditemukan pada keempat lokasi penelitian sebanyak 8 jenis, yaitu $T$. hemprichii, Cymodocea serrulata, C. rotundata, Enhalus acoroides, $H$. pinifolia, Syringodium isoetifolium, $H$. uninervis, dan Halophila ovalis. Perairan 
pesisir Pulau Ambon yakni di lokasi Suli ditemukan 6 jenis, Paperu 5 jenis, Pulau Osi 5 jenis dan Marsegu 6 jenis. Setiap ekosistem lamun memiliki kerapatan jenis lamun yang sangat bervariasi, yaitu penyebarannya dipengaruhi oleh topografi pantai, dan jenis substrat (Riniatsih, 2016). Jenis $T$. hemprichii, $C$. serrulata, dan $H$. uninervis merupakan jenis lamun yang ditemukan pada seluruh stasiun penelitian. Hasil analisis kerapatan jenis lamun (Table 2 dan Table 3) menunjukkan nilai kerapatan total yang tertinggi ditemukan pada lokasi Suli stasiun 2 sebesar 135.968 ind $/ 100 \mathrm{~m}^{2}$ dan terendah berada pada Paperu stasiun 3 yaitu 7.977 ind $/ 100 \mathrm{~m}^{2}$.

Jenis lamun yang memiliki kerapatan tertinggi adalah $T$. hemprichii berkisar antara 2.113 hingga $38.186 \mathrm{ind} / 100 \mathrm{~m}^{2}$ dengan jumlah total seluruh stasiun sebesar 193.222 ind/100 $\mathrm{m}^{2}$. Tingginya nilai kerapatan ini karena $T$. hemprichii memiliki kemampuan adaptasi yang tinggi terhadap semua tipe substrat, hal ini didukung oleh penelitian $\mathrm{Wu}$ et al. (2016) bahwa T. hemprichii hidup pada semua jenis substrat yang bervariasi dari pecahan karang hingga substrat lunak biasanya membentuk padang lamun yang padat (Fitrian et al., 2017). Umumnya $T$. hemprichii dapat ditemukan hampir di seluruh perairan Indonesia dan mampu hidup dengan baik pada substrat berpasir dengan diameter yang besar.

$C$. serrulata, dan $H$. uninervis yang ditemukan pada seluruh stasiun juga diduga disebabkan oleh kondisi substrat yang sesuai, dimana hampir seluruh stasiun pengamatan didominasi substrat pasir. H. uninervis lebih banyak hidup pada pasir halus hingga kasar di zona intertidal dan subtidal.

C. serrulata yang hidup pada daerah dangkal yang tertutup pasir dan memiliki toleransi tinggi pada daerah terbuka. Jenis lamun E. acoroides memiliki kemampuan beradaptasi terhadap berbagai tipe substrat namun jenis ini tidak ditemukan pada stasiun Paperu 1 dan Paperu 2, hal ini diduga karena substrat kedua stasiun tersebut ditemukan juga karang-karang keras, sehingga tidak mendukung kehidupan lamun E. acoroides (Mercier et al., 2000; Ismet et al., 2016).

Jenis $S$. isoetifolium memiliki nilai kerapatan berkisar dari 6.615 sampai dengan $7.900 \mathrm{ind} / 100 \mathrm{~m}^{2}$, dan hanya ditemukan pada lokasi Suli yaitu pada stasiun 1, stasiun 2, stasiun 3 dan berasosiasi dengan jenis lamun yang lain. Philips \& Menez (1988) dan Short et al. (2007) menjelaskan bahwa $S$. isoetifolium merupakan jenis lamun dengan penyebaran yang terbatas dan memiliki toleransi yang sempit terhadap kekeringan dan tidak ditemukan pada tempat-tempat yang mengalami pemaparan jangka panjang saat surut rendah, selain itu bentuk morfologi daunnya tidak memungkinkan air terperangkap di antara daun. Hal ini berbeda dengan lamun yang memiliki daun tipis dan sering saling melekat dan memerangkap air diantara daun, sehingga dapat bertahan terhadap pemaparan matahari yang lebih lama (Koch et al., 2006).

H. ovalis memiliki kerapatan rendah $900 \mathrm{ind} / 100 \mathrm{~m}^{2}$ sampai dengan $2.580 \mathrm{ind} / 100$ $\mathrm{m}^{2}$ dengan jumlah total keseluruhan stasiun hanya sebesar $6.820 \mathrm{ind} / 100 \mathrm{~m}^{2}$, hal ini disebabkan karena $H$. ovalis juga memiliki penyebaran yang sempit dan hanya terbatas di dekat daratan dengan substrat berpasir,

Table 2. The value of $b, R^{2}, r$ and $K n$.

\begin{tabular}{lccccc}
\hline Species & Total $(\mathrm{N})$ & $\mathrm{B}$ & $\mathrm{R}^{2}$ & $\mathrm{r}$ & Kn \\
\hline H. atra & 65 & 1.60 & 0.60 & 0.77 & 1.11 \\
H. scabra & 132 & 1.59 & 0.56 & 0.74 & 1.10 \\
B. marmorata & 43 & 2.07 & 0.67 & 0.81 & 1.11 \\
\hline
\end{tabular}

Information: $B=$ Length-Weight Coefficient, $R^{2}=$ Determination Coefficient, $K n=$ Condition Factor 
Table 3. The seagrass species and density in Ambon Island (ind/100 $\mathrm{m}^{2}$ ).

\begin{tabular}{lccccccc}
\hline \multirow{2}{*}{ Type Seagrass } & \multicolumn{3}{c}{ Ambon Island (Suli) } & \multicolumn{3}{c}{ Ambon Island (Paperu) } & \multirow{2}{*}{ Total } \\
\cline { 2 - 6 } & St 1 & St 2 & St 3 & St 1 & St 2 & St 3 & \\
\hline T. hemprichii & 25,923 & 38,186 & 18,245 & 6,395 & 8,541 & 4,136 & 10,1427 \\
C. serrulate & 7,516 & 15,311 & 16,611 & 1,084 & 4,542 & 426 & 45,489 \\
C. rotundata & 0 & 2,053 & 5,512 & 94 & 371 & 0 & 8,029 \\
E. acoroides & 10,682 & 11,218 & 7,545 & 0 & 0 & 2,605 & 32,050 \\
S. isoetifolium & 7,900 & 6,615 & 6,965 & 0 & 0 & 0 & 21,480 \\
H. uninerves & 21,350 & 3,050 & 11,220 & 1,780 & 2,440 & 810 & 40,650 \\
Total & 73,370 & 135,968 & 128,783 & 9,353 & 15,893 & 7,977 & \\
\hline
\end{tabular}

Table 4. The seagrass species and density in Osi and Marsegu Island (ind/100 $\mathrm{m}^{2}$ ).

\begin{tabular}{lccccccc}
\hline \multirow{1}{*}{$\begin{array}{c}\text { Type } \\
\text { Seagrass }\end{array}$} & \multicolumn{3}{c}{ Island Osi } & \multicolumn{3}{c}{ Island Marsegu } & \multirow{2}{*}{ Total } \\
\cline { 2 - 7 } St & St 2 & St 3 & St 1 & St 2 & St 3 & \\
\hline T. hemprichii & 26,336 & 20,509 & 27,986 & 2,114 & 10,259 & 4,591 & 91,795 \\
C. serrulate & 4,147 & 1,358 & 10,447 & 38,963 & 43,926 & 2,016 & 100,857 \\
C. rotundata & 0 & 0 & 0 & 547 & 471 & 0 & 1,017 \\
E. acroides & 3,586 & 491 & 491 & 545 & 3,377 & 4,482 & 12,972 \\
H. pinifolia & 0 & 0 & 0 & 2,700 & 0 & 0 & 2,700 \\
H. uninervis & 50,900 & 11,470 & 28,130 & 2,050 & 5,580 & 310 & 98,440 \\
H. ovalis & 1,880 & 900 & 1,460 & 2,580 & 0 & 0 & 6,820 \\
Total & 86,850 & 34,727 & 68,514 & 49,499 & 63,613 & 11,398 & \\
\hline
\end{tabular}

dibandingkan lamun jenis lain dengan penyebaran yang lebih luas. Hal ini sesuai dengan pernyataan Nienhuis et al. (1989) bahwa $H$. ovalis sering terlihat sebagai jenis pembuka yang mendiami substrat pasir. Short et al. $(2007 ; 2016)$ juga menjelaskan bahwa Halophila dan Halodule merupakan jenis pioner yang biasanya ditemukan di pesisir pantai, dan kedua jenis lamun tersebut utamanya menempati substrat yang lembab, sehingga dari 8 jenis lamun yang ditemukan jenis lamun yang memiliki kerapatan terendah adalah $H$. pinifolia (Table 4) yaitu sebesar 2700 ind/100 $\mathrm{m}^{2}$ dan hanya ditemukan pada lokasi Pulau Marsegu stasiun 1.

\subsection{Asosiasi Teripang dengan Lamun}

Hasil analisis koresponden (CA) antara $H$. atra, $H$. scabra, dan B. marmorata dengan lamun membentuk 2 sumbu utama dengan ragam total $76,22 \%$ dan menunjukkan adanya hubungan yang erat antara $H$. scabra, H. atra, B. marmorata dengan jenis lamun. Ketiga jenis teripang tersebut memiliki asosiasi berbeda dengan jenis lamun di setiap stasiun penelitian, dan membentuk tiga kelompok asosiasi (Figure 5).

Kelompok pertama mengasosiasikan (PBM) B. marmorata di stasiun paperu, $H$. scabra (OHS) dan H. atra (OHA) pada stasiun Osi serta $H$. scabra (MHS) stasiun Marsegu dengan jenis lamun T. hemprichii, E. acoroides dan $H$. uninervis pada kerapatan $>2.500-7.500$ ind $/ 100 \mathrm{~m}^{2}$ dan kerapatan $>7.500-10.000 \mathrm{ind} / 100 \mathrm{~m}^{2}$. Kelompok kedua mengaitkan H. scabra (SHS) di stasiun Suli dengan H. scabra (PHS) di Paperu dengan jenis lamun $C$. rotundata pada kerapatan $>12.500-17.500$ ind $/ 100 \mathrm{~m}^{2}$ dan kerapatan $>17.500$ ind $/ 100 \mathrm{~m}^{2}$. Kelompok ketiga mengaitkan $H$. atra (SHA) dan B. marmorata (SBM) pada stasiun Suli serta $H$. atra (MHA) pada stasiun Marsegu dengan jenis lamun $C$. serrulata.

Perbedaan sebaran tersebut diduga akibat perbedaan preferensi dari jenis lamun 


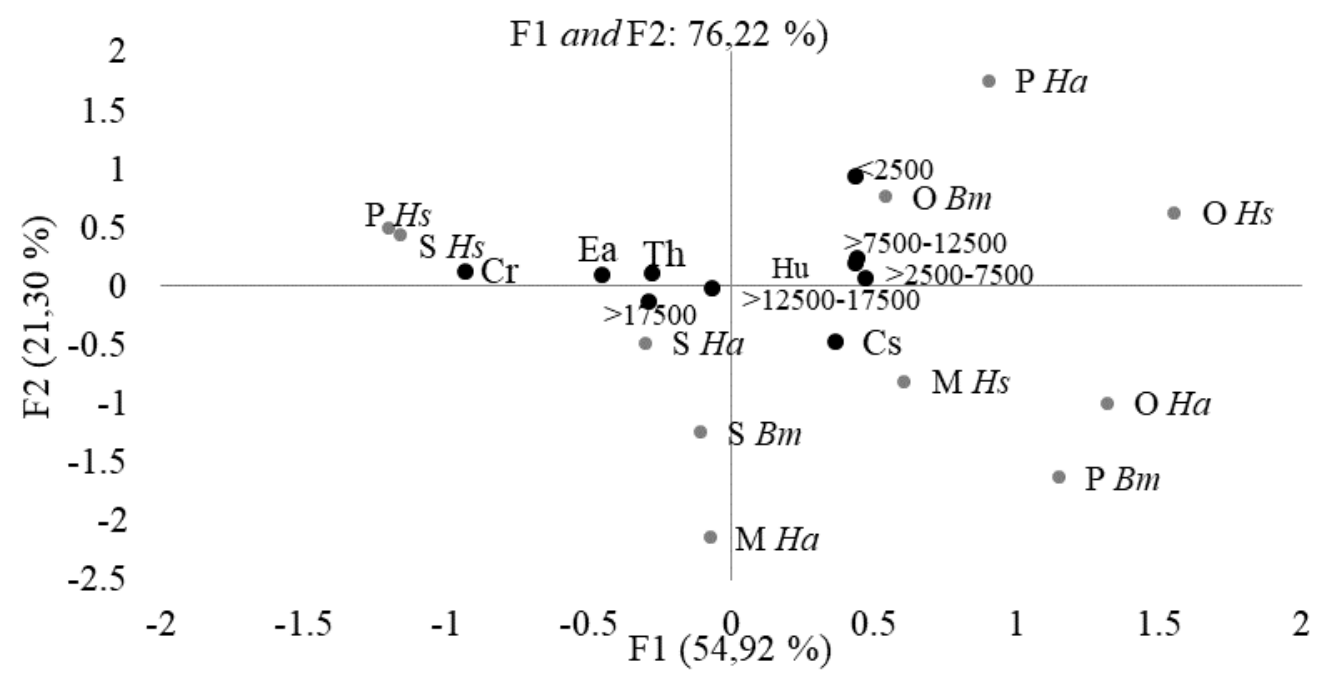

Figure 5. Correspondence analysis (CA)-seagrass and sea cucumber. Information: $P H s=$ H. scabra in Paperu; P Ha=H. atra in Paperu; P Bm=B. marmorata in Paperu; $S H s=H$. scabra in Suli; $S H a=H$. atra in Suli; $S$ Bm=B. marmorata in Suli; $O$ $H s=H$. scabra in Osi; O Ha=H. atra in Osi; O Bm=B. marmorata in Osi; $M$ $H s=H$. scabra in Marsegu; $M$ Ha=H. atra in Marsegu; Hu=H. uninervis; Th= T. hemprichii; $C r=C$. rotundata; $C s=C$. serrulate; $E a=E$. acoroides.

terhadap jenis teripang yang dipengaruhi oleh substrat, kandungan nutrien, dan aktivitas manusia atau masyarakat yang berada di sekitar lokasi penelitian (Dissanayake \& Stefansson, 2012). Umumnya teripang adalah pemakan deposit berupa plankton, detritus, dan kandungan zat organik yang berada di dalam lumpur atau pasir (Wisesa et al., 2018) dan umumnya akan berkumpul pada lamun yang rapat. Menurut Dissanayake \& Stefansson, (2012) berkumpulnya teripang tertentu pada suatu habitat menunjukkan bahwa keberadaan teripang tersebut dipengaruhi oleh ketersedian sumber bahan makanan pada habitat tersebut. Daerah lamun yang rapat diduga kaya akan akumulasi partikel dan detritus yang merupakan bahan makanan teripang. Kerapatan jenis lamun $T$. hemprichii merupakan jenis yang paling tinggi dibandingkan dengan jenis yang lain. Hamsiah et al. (2016) menjelaskan bahwa lamun jenis ini memiliki jumlah yang cukup berlimpah dan lebih dominan pada padang lamun campuran, tingginya kerapatan jenis lamun juga berdampak pada jenis teripang yang hidup berasosiasi dengannya. Lamun jenis $T$. hemprichi dan E. acroides tergolong dalam kategori lamun yang berukuran besar, sehingga memiliki toleransi yang lebih luas dibandingkan lamun yang berukuran kecil seperti $H$. uninervis, $C$. rotundata, $C$. serulata $H$. ovalis, $H$. pinifolia, $S$. isoetifolium, serta memiliki kerapatan lebih tinggi dibandingkan dengan jenis lamun yang lain, sehingga dapat ditemukan ketiga jenis teripang tersebut. Umumnya jenis lamun berukuran besar menghasilkan bahan organik lebih besar dibandingkan jenis lamun berukuran kecil dan menjadi daya tarik bagi teripang sebagai tempat berlindung yang aman dari ancaman predator dan sebagai sumber bahan makanan, dan memiliki kemampuan untuk memerangkap sedimen yang mengandung bahan organik dari lautan dan daratan melalui ketebalan daunnya dan sistem perakaran yang kuat.

Slater et al. (2011) menjelaskan teripang cenderung berkonsentrasi di daerah dengan tingkat bahan organik yang tinggi. Analisis regresi yang dilakukan antara teripang $H$. scabra, $H$. atra, dan $B$. marmorata dengan 8 jenis teripang lamun 
yang ditemukan dikategorikan ke dalam dua kelompok. Kelompok pertama adalah kelompok jenis lamun berukuran besar yaitu jenis $T$. hemprichii dan E. acoroides sedangkan kelompok kedua adalah kelompok jenis lamun berukuran kecil yaitu jenis $C$. serrulata. $C$. rotundata, $S$, isoetifolium, $H$. uninervis, $H$. ovalis dan $H$. pinifolia. Hasil analisis menunjukkan bahwa jenis $H$. scabra memiliki hubungan erat dengan jenis lamun berukuran besar sebesar 0,86 (Figure 6) dan memiliki hubungan yang sangat kecil dengan jenis lamun berukuran kecil yang hanya sebesar 0,14. Hasil ini menunjukkan bahwa jenis teripang ini juga adalah pemakan serasah lamun. Jenis $H$. atra memiliki hubungan erat dengan lamun kelompok ukuran besar dan juga jenis lamun kelompok

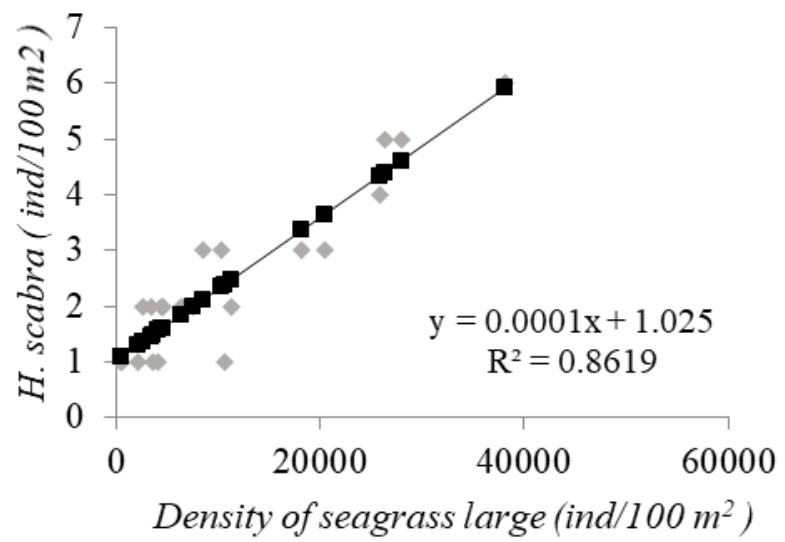

ukuran kecil (Figure 7), hasil regresi menunjukkan hubungan sebesar 0,58 dengan kelompok lamun ukuran besar dan 0,41 dengan kelompok jenis lamun ukuran kecil. Jenis $B$. marmorata ditemukan memiliki regresi yang lebih besar dengan jenis lamun ukuran besar yaitu sebesar 0,64 (Figure 8) dibandingkan jenis lamun ukuran kecil yang hanya 0,34 .

Hasil ini menunjukkan $H$. scabra, $H$. atra, dan B. marmorata merupakan jenis teripang dapat ditemukan pada jenis lamun berukuran besar yaitu $T$. hemprichii dan $E$. acoroides. Hal ini dikarenakan jenis lamun besar memiliki kanopi daun dan nutrien yang besar serta memiliki waktu hidup yang jauh lebih panjang dibandingkan jenis lamun kecil.

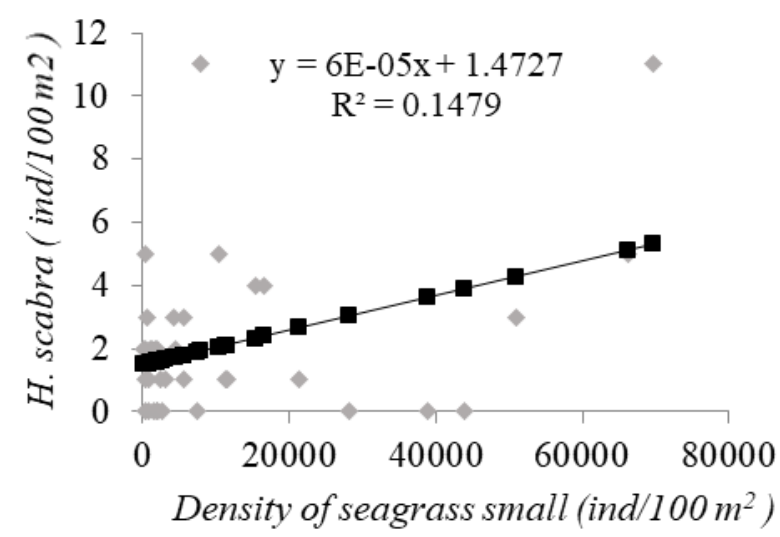

Figure 6. Regression results between the seagrass and $H$. scabra.
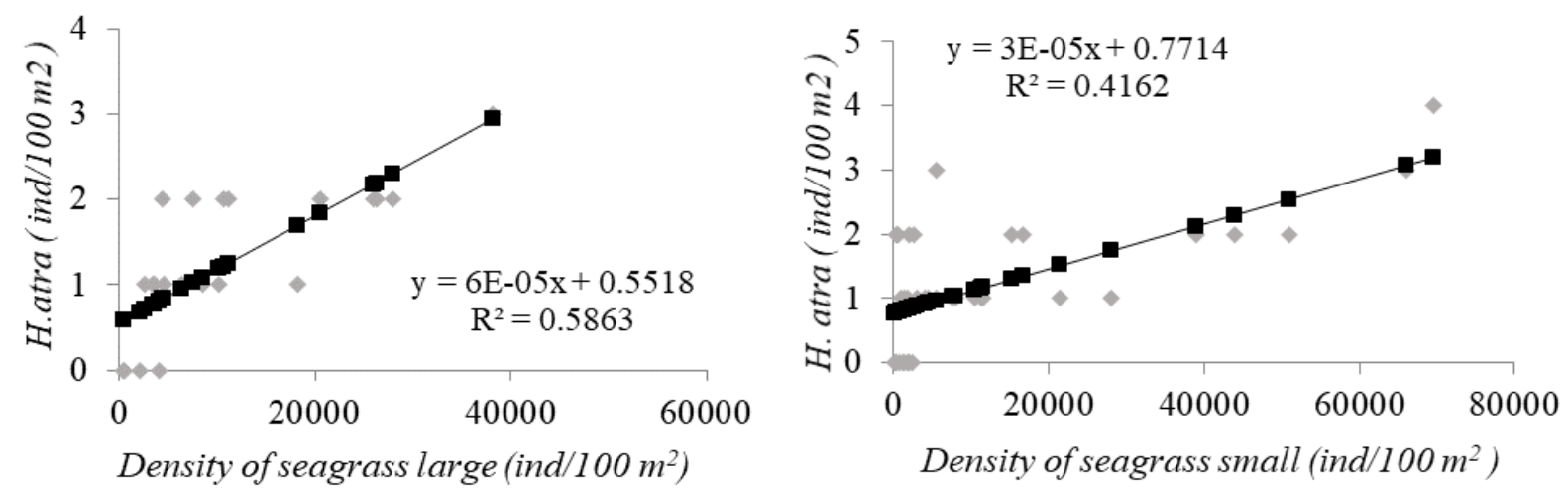

Figure 7. Regression results between the seagrass and $H$. atra. 

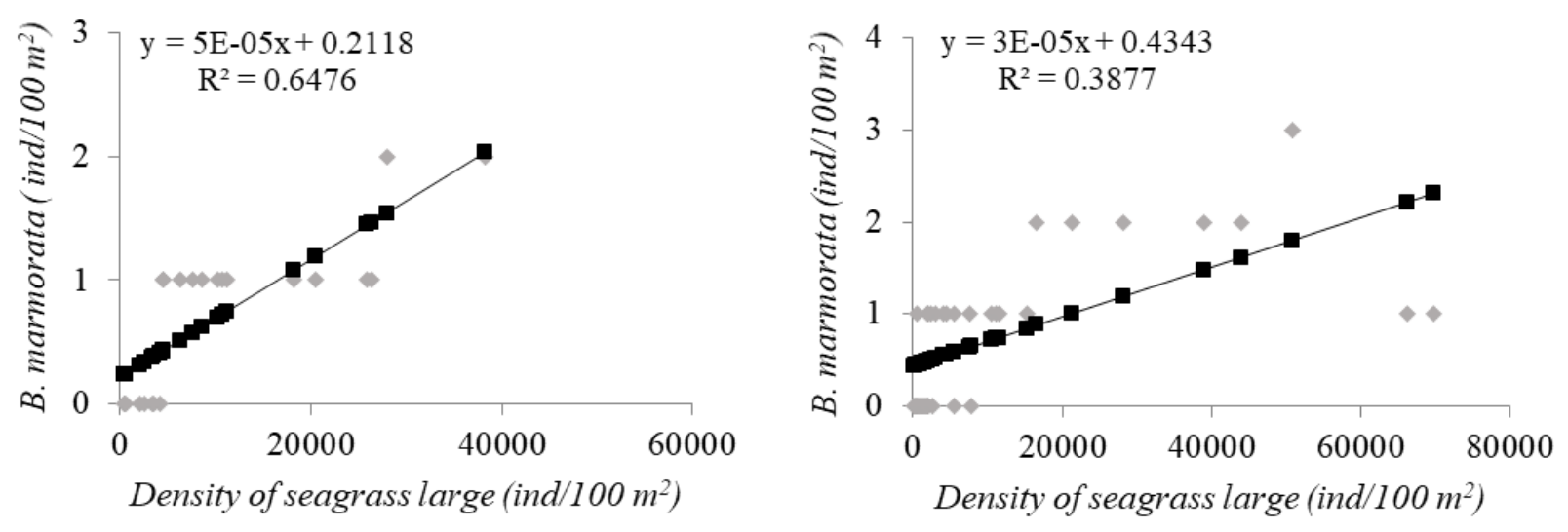

Figure 8. Regression results between the seagrass and B. marmorata.

\section{KESIMPULAN}

Kepadatan teripang jenis $H$. scabra, $H$. atra, dan B. marmorata ditemukan tertinggi di Pulau Ambon lokasi Suli dan rendah pada Pulau Marsegu dengan pola pertumbuhan pada kedua lokasi adalah allometrik negatif dan kondisi teripang yang gemuk. Kerapatan jenis lamun tertinggi pada seluruh stasiun adalah jenis T. hemprichii ditemukan pada Pulau Ambon lokasi Suli dan terendah adalah jenis $H$. pinifolia pada Pulau Marsegu stasiun 1. Teripang jenis $H$. scabra dan $B$. marmorata memiliki hubungan yang erat dengan jenis lamun berukuran besar sedangkan jenis $H$. atra memiliki hubungan regresi hampir sama antara jenis lamun berukuran besar dan jenis lamun berukuran kecil.

\section{UCAPAN TERIMA KASIH}

Penulis menyampaikan terima kasih kepada Pemerintah Daerah Provinsi Maluku yang telah memberikan beasiswa kepada penulis serta teman-teman tim di lapangan yang telah membantu pengambilan data (Brian Uneputty, Sandy Lameky, Ray Bakarbessy Erwin Kay dan Jelien Noya).

\section{DAFTAR PUSTAKA}

Bengen, D.G. 2000. Sinopsis teknik pengambilan contoh dan analisa data biofisik sumberdaya pesisir. IPB Press. Bogor. 85 p.

Bengen, D.G. 2001. Sinopsis ekosistem dan sumberdaya alam pesisir dan laut. IPB Press. Bogor. 63 p.

Braun-Blanquet. 1965. Plant sociology; the study of plant communities. Hafner Publishing Company. The University of Michigan. 439 p.

Bordbar, S.A. Farooq, \& S. Nazamid. 2011. High-value components and bioactives from sea cucumbers for functional food. Marine drugs, 9(10): 1761-1805. https://doi.org/10.3390/md9101761

Direktorat Jenderal Perikanan Tangkap. 2010. Statistik perikanan tangkap Indonesia, tahun 2008. Dirjen Perikanan Tangkap. Kelautan dan Perikanan. Jakarta. 130 pp.

Dissanayake, D.C.T. \& G. Stefansson. 2010. Abundance and distribution of commercial sea cucumber species in the coastal waters of Sri Lanka. J. Aquat. Living Resour, 23: 303-313. https://doi.org/10.1051/alr/2010031

Dissanayake, D.C.T. \& G. Stefansson. 2012. Habitat preference of sea cucumbers: Holothuria atra and Holothuria edulis in the coastal waters of Sri Lanka. J. of The Marine Biological Association of The United Kigdom, 92(2): 581-590. 
https://doi.org/10.1017/S0025315411 000051

Effendie, M.I. 1979. Metode Biologi Perikanan. Yayasan Dewi Sri. Bogor. $112 \mathrm{p}$.

English, S.C. Wilkinson, \& V. Baker. 1994. Survey manual for tropical Marine resources. ASEAN-Australia Marine Science Project. Australia. 368 p.

Fagetti, A.G. \& F.B. Villalobos. 2016. Spatio-temporal variation in density and size structure of the endangered sea cucumber Isostichopus fuscus in Huatulco National Park, Mexico. Marine ecology, 38(1): 1-11. https://doi.org/10.1111/maec.12386

Fitrian, T., K. Agus, \& N.P. Rosmi. 2017. Seagrass community structure of Tayando-Tam Island Southeast Moluccas Indonesia. Biodiversitas, 18(2): 788-794. https://doi.org/10.13057/biodiv/d1802 50

Guliano, G.A.S, B. Sulardiono, \& F. Purwati. 2014. Kelimpahan teripang di perairan terbuka dan perairan tertutup Pulau Panjang Jepara, Jawa Tengah.

J. of maquares. 3(1): 108-115. https://publications/150919-ID-

kelimpahan-jenis-teripang-diperairan-te.pdf

Gutierrez, M.B., C.A.F. Sebastian, K. Andreas, M.S. Selina, E.M. Flower, S.H. Thomas, \& J.S. Matthew. 2014. Co-culture of sea cucumber Holothuria scabra and red seaweed Kappaphycus striatum. Aquaculture Reasearch, 47(5): 1-11. https://doi.org/10.1111/are.12651

Hamel, J.F., C. Chantal, L.P. David, \& M. Annie. 2001. The sea cucumber Holothuria scabra (Holothuroidea Echinodermata): Its biology and exploitation as Beche-de-mer. Marine Biology, 41: 129-223. https://doi.org/10.1016/S00652881(01)41003-0
Hamsiah, Y.H. Endang, M. Mohammad, \& S. Adi. 2016. Diversity of seagrass relation with environmental characteristics in the Labakkang coastal waters, Pangkep, South Sulawesi Indonesia. IOSR, 10(6): 3341. https://doi.org/10.9790/24021006033341

Hartati R., A. Trianto, \& Widianingsih. 2017. Habitat characteristic of two selected locations for sea cucumber ranching purposes. IOP Conf. Series. Earth and Environmental Science. 55(1): 012041. http://doi.org/10.1088/17551315/55/1/012041

Hasan, M.H. 2005. Destruction of a Holothuria scabra population by overfishing at Abu Rhamada Island in the Red Sea. Marine environmental research, 60: 489-511.

https://doi.org/10.1016/j.marenvres.2 004.12.007

Ismet, M.S., D.G. Bengen, Radjasa, \& M. Kawaroe. 2016. Komposisi aktivitas antibakteri spons laut dari ekosistem lamun yang berbeda di perairan Kepulauan Seribu, Jakarta. J. Ilmu dan Teknologi Kelautan Tropis, 8(2): 729-745. https://doi.org/10.28930/jikt.v8i2.158 38

Kaenda, H., I. Ermayanti, \& O.A.A. La. 2016. Hubungan panjang berat teripang di perairan Tanjung Tiram Konawe Selatan. Manajemen Sumber Daya Perikanan, 2(2): 171-177. https://Hubungan-panjang-beratteripang-di-perairan-tanjung-tiramkonawe selatan.html

Koch, E.W., J.V. Jennifer, A. Joseph, \& M.D. Carlos. 2006. Fluid dynamics in seagrass ecology from molecules. Biology Ecology and Conservation: 193-225. https://doi.org/10.1007/14020-2983-7_8

Krebs, C.J. 1978. Ecology methodology. Harper and kow publisher. New York. 654 p. 
Le Cren, E.D. 1951. The length-weight relationship and seasonal cyle in gonad weight and condition in the perch (Perca fluviatilis). J. Animal Ecology, 20(2): 201-219. http://doi.org/10.2307/1540

Lee, J.M., S. Byme, \& Uthicke. 2008. The influence of population density on fission and growth of Holothuria atra in Natural Mesocosm. Marine Biologi Ecol., (363): 126-135. https://doi.org/10.1016/j.jembe.2008. 08.003

Mercier, A., C.B. Stephen, \& F.H. Jean. 2000. Settlement preferences and early migration of the tropical sea cucumber Holothuria scabra. J. Exp. Bio. Ecol., 249(1): 89-110. http://doi.org/10.1016/S00220981(00)00187-8

Mulyani, L.F. Marsoedi, \& Guntur. 2017. An application of geographic information system to identify the suitability af sea cucumber (Holothuria scabra) in west Lombok waters. J. of Indonesia Tourism and Development Studies, 5(3): 155-160.

https://doi.org/10.21776/ub.jitode.201 7.005.03.03

Namukose, M.F., E. Msuya, S.C.A. Ferse, \& M.J. Slater. 2016. Growth performance of the sea cucumber Holothuria scabra and the seaweed Eucheuma denticulatum: integrated mariculture and effects on sediment organis characteristics. Aquaculture Environment Interactions, 3: 179189. https://doi.org/10.3354/aei00172

Newmaster, A.F., K.J. Berg, S. Ragupathy, M. Palanisamy, K. Sambandam, \& S.G. Newmaster. 2011. Local knowladge and conservation of seagrass in the Tamil Nadu State of India. Ethnobiology and Ethnomedicine, 7(37): 1-17. https://doi.org/10.1186/1746-4269-737
Nienhuis, P.H., J. Coosen, \& W. Kiswara. 1989. Community structure and biomass distribution of seagrasses and macrofauna in the Flores Sea, Indonesia. Sea Research, 23(2): 197214. https://doi.org/10.1016/00777579(89)90014-8

Philips, R.S., \& E.G. Menez. 1988. Seagrasses. Smithsonian Institute Press. Washington DC. 104 p.

Purcell, S.W., B.A. Polidoro, J.F. Hamel, Gamboa, \& A. Mercier. 2014. The cost of being valuable: predictors of extinction risk in marine invertebrates exploited as luxury seafood. Biological sciences, 281(1781): 20133296.

https://doi.org/10.1098/rspb.2013.329 6

Purcell, S., U. Sven, C. Chantal, \& B. Maria. 2016. Ecological roles of exploited sea cucumbers. Oseaography and marine biology, 54: 367-386. http://doi.org/10.1201/978131536859 7-8

Ricker, W.E. 1975. Computation and interpretation of biological statistics of fish populations. Bull fish Res Board of Canada. Ottawa. 283 p.

Riniatsih, I. 2016. Distribusi jenis lamun dihubungkan dengan sebaran nutrient perairan di padang lamun Teluk Awur Jepara. J. Kelautan Tropis. 19(2): 101-107.

https://doi.org/10.14710/jkt.v19i2.824

Ristina, M., M. Sulardiono, \& A. Solichin. 2018. Hubungan kerapatan lamun (seagrass) dengan kelimpahan teripang (Holuturia) di pantai alangalang Taman nasional Karimunjawa. J. of maquares, 7(4): 452-457. https://ejournal3.undip.ac.id/index.ph $\mathrm{p} / \mathrm{maquares} /$ article/view/22669

Short, F., T. Carruthers, W. Dennison, \& M. Waycott. 2007. Global seagrass distribution and diversity: A bioregional model. J. Exp. Bio. Ecol., 350(2007): 3-20. 
https://doi.org/10.1016/j.jembe.2007. 06.012

Short, F.T., C.A. Short, \& A.B. Novak. 2016. Seagrasses. In: Finlayson C., Milton G., Prentice R., Davidson N. (eds) The Wetland Book. Springer, Dordrecht. 1-19 pp. https://doi.org/10.1007/978-94-0076173-5_262-1

Slater, M.J., A.G. Jeffs, \& M.A. Sewell. 2011. Organically selective movement and deposit-feeding in juvenile sea cucumber, Australia stichopus mollis determined in situ and in the laboratory. Marine Biology and Ecology, (409): 315-323.

https://doi.org/10.1016/j.jembe.2011. 09.010

Wisesa, M.M., D. Bakti, \& A. Fadhilah. 2018. Abudance of sea cucumber on thr ecosystem of seagrass Inunggeh Island, Tapanuli Tengah Regency North Sumatera Province. IOP, 122: 1-8. https://doi.org/10.1088/17551315/122/1/012107
Wu, K., N.N.C. Ching, \& S. Keryea. 2016. Long Distance dispersal potential two seagrass Thalassia hemprichii and Holophila ovalis. Plos One, 11(6): e0156585.

https://doi.org/10.1371/journal.pone.e 156585

Yusron, E. \& P. Widiansari. 2004. Struktur komunitas teripang (Holothuroidea) di beberapa perairan Maluku Tenggara. Makara Sains. 8(1): 15-20. http://journal.ui.ac.id/index.php/scien ce/article/view/385

Zamora, L.N. \& A. Jeffs. 2011. A riview of the research on the Australasian sea cucumber Australostich mollis (Echinodermata Holothuroidea (Hutton 1872) with Emphasis on aquaculture. J. Shellfish, 32(3): 613627.

https://doi.org/10.2983/035.032.0301

Received : 1 December 2018

Reviewed : 17 November 2019

Accepted : 20 August 2020 